\title{
FACIES ASSOCIATIONS AND MICROFOSSILS FROM THE MIDDLE-UPPER TRIAS- SIC LIMESTONES OF THE TRANSILVANIAN NAPPES (PERŞANI MOUNTAINS, EASTERN CARPATHIANS, ROMANIA)
}

\author{
Cristian Victor Mircescu ${ }^{1}$, Ioan I. Bucur ${ }^{1,2}$, Ștefania Ghionea $^{1} \&$ George Leonard Popa $^{1}$
}

Received: 7 May 2019 / Accepted: 23 July 2019 / Published online: 30 July 2019

\begin{abstract}
Triassic limestones that belong to the Transilvanian Nappe system, form extensive outcrops in the central part of the Perșani Mountains, near Racos locality, on the southern and northernsides of the Olt Gorges. Triassic carbonate olistoliths were sampled in four distinct locations belonging to the Transilvanian Nappe: the Old Racoș Quarry, Olt Gorges, Tipia Racoșului Hill and Tipia Ormenișului Hill. The identified facies types include brecciated limestones with encrusting organisms and cyanobacteria, packstone-grainstone with sponges and encrusting organisms, boundstone with grainstone internal sediment, peloidal wackestone-packstone, peloidal packstone-grainstone, intraclastic grainstone-rudstone. Such microfacies characterize reefal bioconstructions or fore-reef domains located in the vicinity of shelf crest areas. They share common features with similar Wetterstein facies carbonates from Italy, Austria or Hungary. The micropaleontological assemblage indicates the Anisian-Ladinian to Carnian ages for the studied limestones, the present study bringing new data concerning the age of these carbonates. In addition, the presence of some foraminifera and dasycladalean algae are mentioned for the first time in this area.
\end{abstract}

Keywords: Reefs, Wetterstein facies, Anisian-Ladinian-Carnian, olistoliths, corals, sponges, fore-reef.

\section{INTRODUCTION}

Middle Triassic facies and microfossil associations were studied by numerous authors in many regions of the Tethyan Realm [Gaetani et al., 1981; Buser et al., 1982; Senowbari-Daryan et al. (1993, 2009, 2011, 2015); Flügel et al. 1994; Bucur et al. (1994, 1997); Sanchez-Beristain \& Reitner (2016, 2018, 2019)]. During Middle-Upper Triassic (Anisian to Carnian) shallow-water reefal carbonates were accumulating on a large scale in various locations. Such carbonate deposits were mentioned from Hungary (Balogh \& Kovacs, 1976; Senowbari-Daryan et al., 2011; Velledits et al., 2011; Horvath \& Hips, 2015), Italy (Senowbari-Daryan et al., 1993) or Romania (Popa \& Dragastan, 1973; Istocescu \& Dragastan, 1978; Dragastan et al., 1982; Mantea, 1985; Bucur et al., 1994, 1997; Popescu, 2001; Popescu \& Popescu, 2004). The main purpose of this study is to describe the microfacies and microfossil associations from the Middle-Upper Triassic carbonate olistoliths located in the Transilvanian Nappes of the Perşani Mountains, Racoş area.

\section{GEOLOGICAL FRAMEWORK AND LOCATION OF STUDIED SECTIONS}

The Perșani Mountains are characterized by a very complicated geological structure. Their geological and structural framework consists of two sets of units: the Bucovinian and Transylvanian Nappes (Patrulius et al., 1966; Săndulescu, 1984). Three major units define the Transilvanian Nappe system which overthrusts the Bucovinian Nappe. These units are represented by the Hăghimaş, Perşani and Olt Nappes (Patrulius et al., 1966). They represent fragments originating from different areas of the
Transilvanian oceanic realm (Săndulescu, 1984). Elements belonging to the Transilvanian units were subsequently deposited as olistoliths in various parts of the Eastern Carpathians (Ilie, 1954; Patrulius et al.. 1966; Sandulescu 1984). In the Olt Gorges, the lowermost part of the Bucovinian Nappe consists of Tithonian-Hauterivian pelagic rocks (Carhaga Formation) covered by flysch and wildflysch type deposits (Patrulius et al., 1966) (Fig. 1a-d). The latter contain clays interbedded with coarse sandstones and fine quartzitic sandstones (Popescu et al., 1976). Patrulius et al. (1966) assigned them to the Barremian-Aptian (Bedoulian) interval. The Wildflysch Formation incorporates Lower Triassic (Campilian) to Hauterivian carbonate and siliciclastic olistoliths in association with Ladinian mafic rocks (Patrulius et al., 1966). All these olistoliths are derived from the Olt and Perşani Nappes or the Carhaga Formation Fig. 1a-b, d). The post-tectonic cover contains upper Aptian polimictic conglomerates and Aptian (Vraconian)-lower Albian (Turonian) calcarenites and sandy limestones (Popescu et al., 1976).

The Wildflysch Formation incorporates four major types of olistoliths (Patrulius, 1996; Patrulius et al., 1996). They include: 1) olistoliths derived from the Perşani Nappe; 2) olistoliths derived from the Olt Nappe; 3) olistoliths and blocks derived from the Transilvanian Zimbru Series (Norian-Rhaetian limestones); 4) olistoliths and rocks derived from the Carhaga Formation (Tithonian-Hauterivian) (Fig. $1 \mathrm{~b})$. The Upper Jurassic Mereşti olistoliths are included in the lowermost part of the Aptian post-tectonic cover (Fig. $1 \mathrm{~b})$.

The Olt Nappe is exposed on large surfaces in the northern part of the Perşani Mountains (Fig. 1 d). Some of the most important exposures are located in the Meghieş area, Hăghimaş Valley, Olt Gorges (Pietrele lui Murgoci, Tipia

\footnotetext{
${ }^{1}$ Babeş-Bolyai University, Department of Geology, 1 M. Kogălniceanu Str., 400084 Cluj-Napoca, Romania;

* Corresponding author: cristianvictormircescu@ hotmail.com.

stefania.ghionea@yahoo.com; george.popa.leonard@gmail.com

${ }^{2}$ Babeş-Bolyai University, Department of Geology and Center for Integrated Geological Studies, 1, M. Kogălniceanu str., 400084 Cluj-Napoca,

Romania; ioan.bucur@ubbcluj.ro;
} 


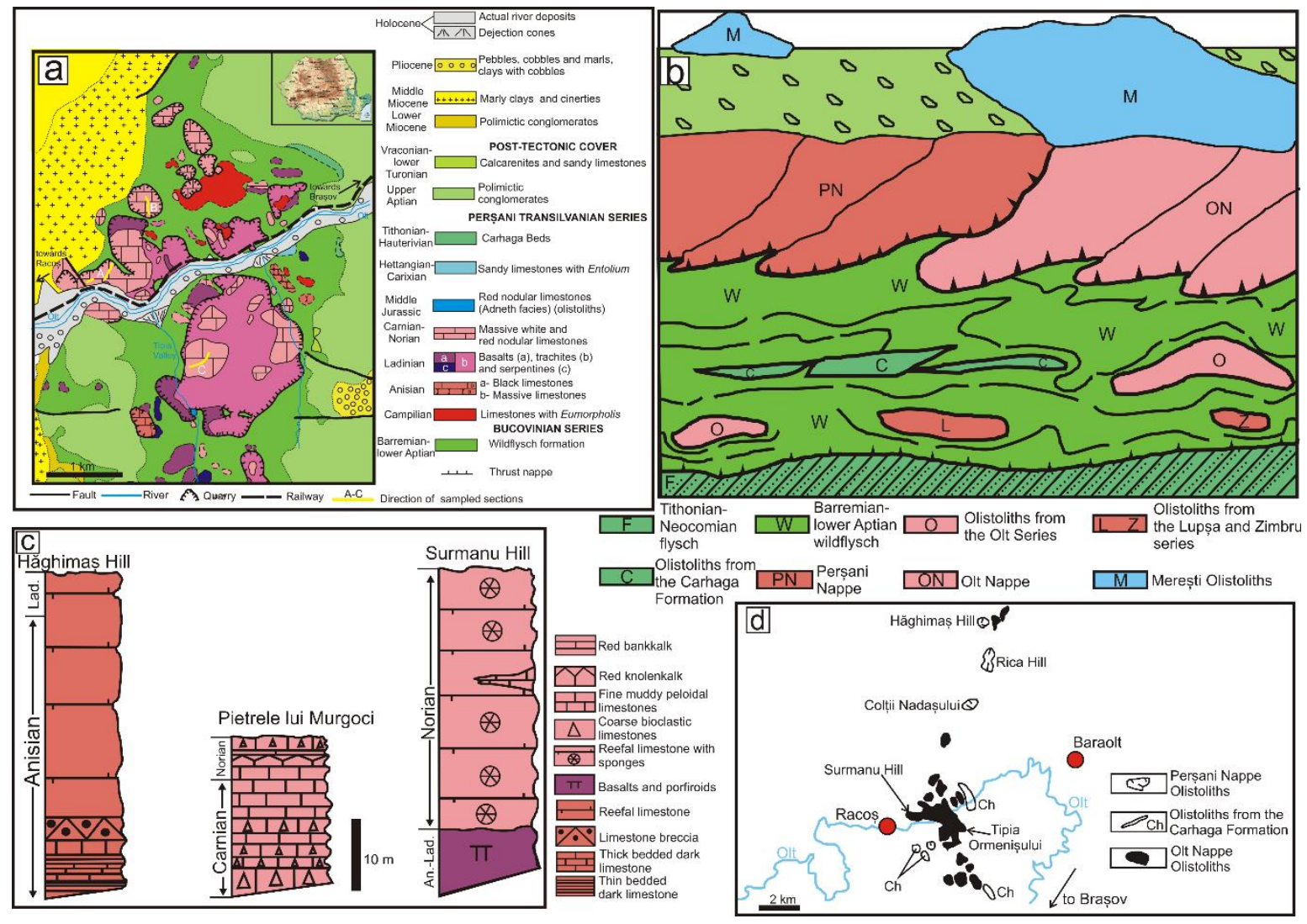

Fig. 1 a Geological map of the studied area and location of studied sections [(A-Olt Gorges section and the Old Racoş Quarry; B-Tipia Racoșului section; C-Tipia Ormenişului section) (redrawn from Popescu et al., 1976)]; b Olistoliths from the Perşani Mountains and their relationship with other sedimentary units (redrawn from Patrulius et al., 1996) (not at scale); c Carbonate successions of the Triassic deposits from the olistoliths belonging to the Perșani and Olt nappes (Hăghimaş, Surmanu and Pietrele lui Murgoci sections) (redrawn from Patrulius et al., 1996); d Distribution of the olistoliths on the teritory of the central and northern Perşani Mountains (redrawn from Patrulius et al., 1996).

Ormenişului) or Surmanu Hill (Patrulius et al., 1996) (Fig. 1c-d).

An ideal vertical succession through the Olt Nappe (based on olistolith rocks) comprises the following units: limestones and thin-bedded clays (Campilian-lower Anisian), meter thick-bedded limestones (lower Anisian), an ophiolitic complex covered by bostonitic porphyres and andesites (lower Anisian-lower Ladinian), Hallstatt type limestones and massive reefal carbonates (lower Carnian-upper Norian) (Fig. 1 c) in association with lower Jurassic Adneth type limestones (Fig. 1 a) (Patrulius et al., 1996).

The carbonate succession from the Olt Gorges is divided in two main categories. The first one includes packages of thin Hallstatt type limestones and massive Norian carbonates which cover Ladinian mafic rocks. They form large outcrops on the Tipia Ormenişului Hill, aproximately $1.5 \mathrm{~km}$ south-east from Olt Gorges. Their Norian age is indicated by Patrulius et al. (1996) based on an assemblage of poorly preserved ammonites (Cladiscites sp., Arcestes sp.) from thin beds of Hallstat type limestones underlying massive reefal limestones. The second category consists of interbeddings of Hallstatt type limestones and coarse carbonates. It forms a well-exposed outcrop in the Pietrele lui Murgoci area, at the confluence between the Olt River and Tipia valley (Fig. 1c).

The carbonate succession from the Perşani Nappe forms extensive outcrops in various locations such as Colţii Nadaşului, Rica Hill or Hăghimaşului Hill. These carbo- nates consist of decimeter- to meter thick stratified limestones and dolomites covered by Steinalm type limestones with abundant foraminifera and dasycladalean algae (Fig. $1 c)$.

\section{MATERIALS AND METHODS}

Three sections were studied: (A-C in Fig. 1a; Fig. 2a-e): Olt Gorges, Tipia Racoșului Hill, Tipia Ormenișului Hill. The Olt Gorges section is divided in two important sectors: The Old Racoș Quarry and the right side of the Olt Gorges (Fig. 2a-c). The first sector is located approximately 200 meters east from the actual Racoș Quarry, in the Surmanul Hill (Fig. 2c). Patrulius et al. (1996) described from this location a detailed section of the Triassic succession. The authors indicate its Norian age based on some bivalve fragments (Monotis haueri Kittl) The second segment of the Olt Gorges section is perpendicular on the Olt river flowpath being located at approximately 100 meters east from the old Racoș Quarry (Fig. 2c). The starting point is represented by a ravine/stream. Altered mafic rocks belonging to the Olt Nappe form the bedrock of this small creek. The final point of this section is located approximately $200 \mathrm{me}-$ ters towards NE (Fig. 2c).

Tipia Racoşului section follows the carbonate olistolith from the Tipia Racoșului hill. It is located approximately two kilometres NE from the Racoș locality and one 

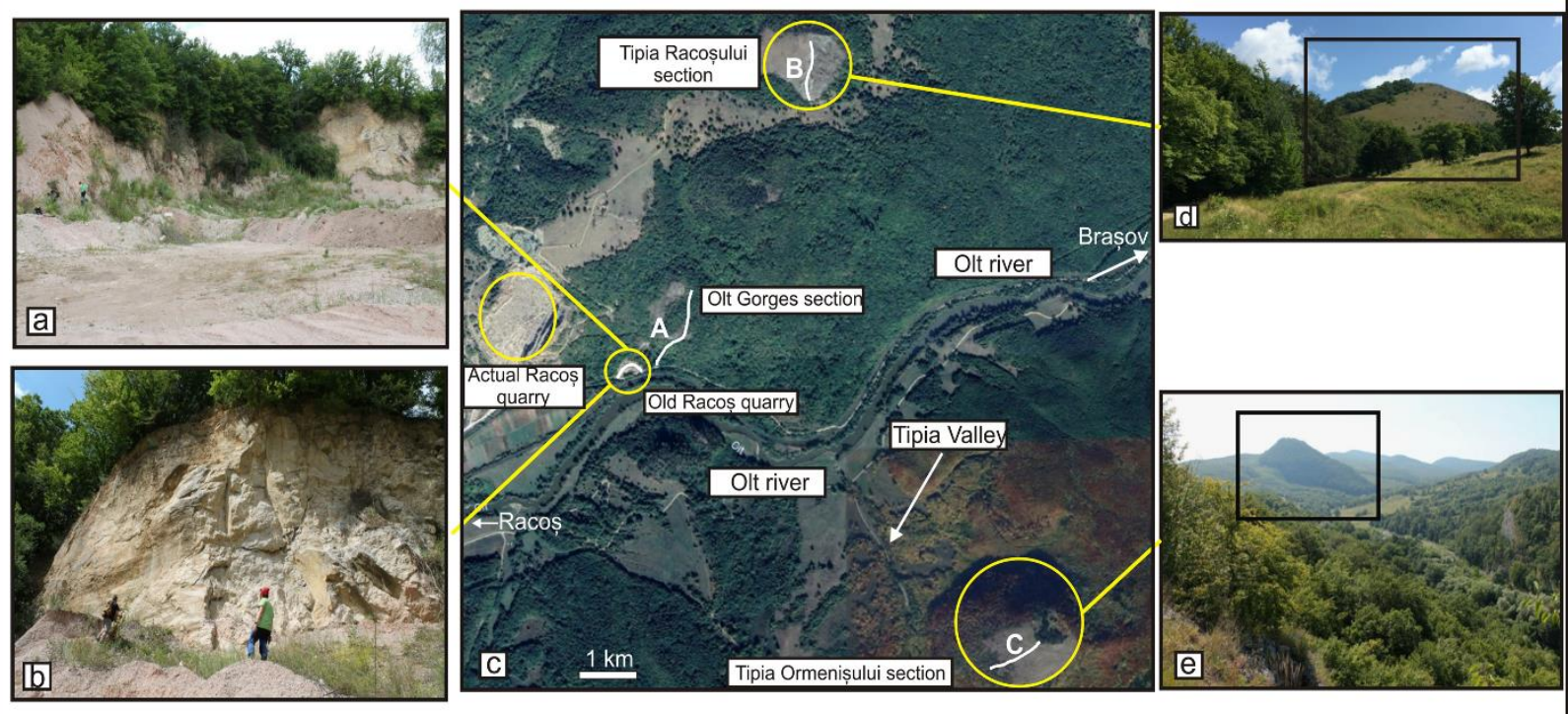

Fig. 2 Outcrop images and location of the studied olistoliths [a, b: outcrops - of the Old Racoș Quarry; $\mathbf{c}$ location of the studied olistoliths and position of the most important topographic elements (A-Old Racoș Quarry and Olt Gorges section, samples 1-31 and 32-100; B-Tipia Racoșului section, samples 101-171; C-Tipia Ormenișului section, samples 172-220); d General view over the Tipia Racoșului Hill (black rectangle); e General view of the Olt Gorges and Tipia Ormenişului Hill (black rectangle).

kilometre north from the ending point of the Olt Gorges section (Fig. 2c-d).

Tipia Ormenişului section is located one kilometre NE from the confluence between Tipia valley and the Olt river. Patrulius et al. (1996) mention its Upper Triassic age and indicate its stratigraphic position within the Olt Nappe. The studied section follows a predominantly SW-NE direction, from the Tipia Valley towards the topmost part of the hill (Fig. 2e).

Two hundred twenty samples were collected from various outcrops associated with carbonate olistoliths belonging to the studied sections. Sampling was performed at 2-3 meters resolution. Two hundred thirty thin sections were analysed for their microfacies and micropaleontological associations. Carbonate rock classification follows Dunham (1962) and Embry \& Klovan (1971).

\section{MICROFACIES}

Four major microfacies associations (MFA1-MFA4) define the studied sections.

Microfacies association 1(MFAl)

This facies association occurs in all the studied sections and dominates the facies spectrum of the Tipia Racoșului section. The most important microfacies types are represented by boundstone with grainstone-type internal sediment, boundstone with recrystallized peloidal wackestonepackstone internal sediment, coral-microbial boundstone, sponge bearing boundstone (Fig. 3a-b). Corals are encrusted by unidentified encrusting organisms and Tubiphytes sp. Some corals present micritised septa. The internal sediment contains encrusting organisms, worm tubes, large calcareous sponges, gastropods, bivalves, echinoderm plates, foraminifera and millimetre-sized angular intraclasts. The major components are embedded in fibrous radiaxial cement.

\section{Interpretation}

These bioconstructions were accumulated in a high energy shelf crest depositional setting. The abundance of encrusting organisms indicates the presence of a rigid, wave resistant shelf margin. The presence of grainstone-type internal sediment confirms high-energy conditions where the waves were washing the muddy sediment deposited inside the bioconstructions. Although rare, the wackestone type internal sediment characterizes deeper water bioconstructions defined by low-energy conditions.

Microfacies association 2 (MFA2)

This facies association comprises the following microfacies: brecciated limestones, intraclastic rudstone, peloidal bioclastic grainstone-rudstone, bioclastic rudstone (Fig. $3 c-d)$. It is very frequent in the Tipia Ormenișului and Tipia Racoșului sections.

Bioclasts consist of coral fragments, encrusting organisms, frequent echinoderm plates, cyanobacteria nodules, bivalves, agglutinated foraminifera and calcareous sponges. Corals are encrusted by microbial structures. Fragments of microbial crusts, thrombolitic structures and worm tubes are common. Microbial crusts contain alternating laminae of spar and microspar or elongated filamentous structures. Voids are filled by abundant fibrous cement. Millimetreto centimetre-sized angular intraclasts are present. They contain micrite and may trap peloids or other bioclasts.

\section{Interpretation}

The presence of angular intraclasts, poor sorting and the frequent occurrence of coral fragments and other reefal bioclasts suggest that carbonate sediments were transported on a short distance, from topographicaly elevated shelf crest areas. These sediments were reworked on a fore-reef slope from adjacent reefal settings. Abundant echinoderm ossicles characterize such normal marine depositional environments. Intense microbial activity led to the formation of thrombolytic structures (Pleș et al. 2013). Although 

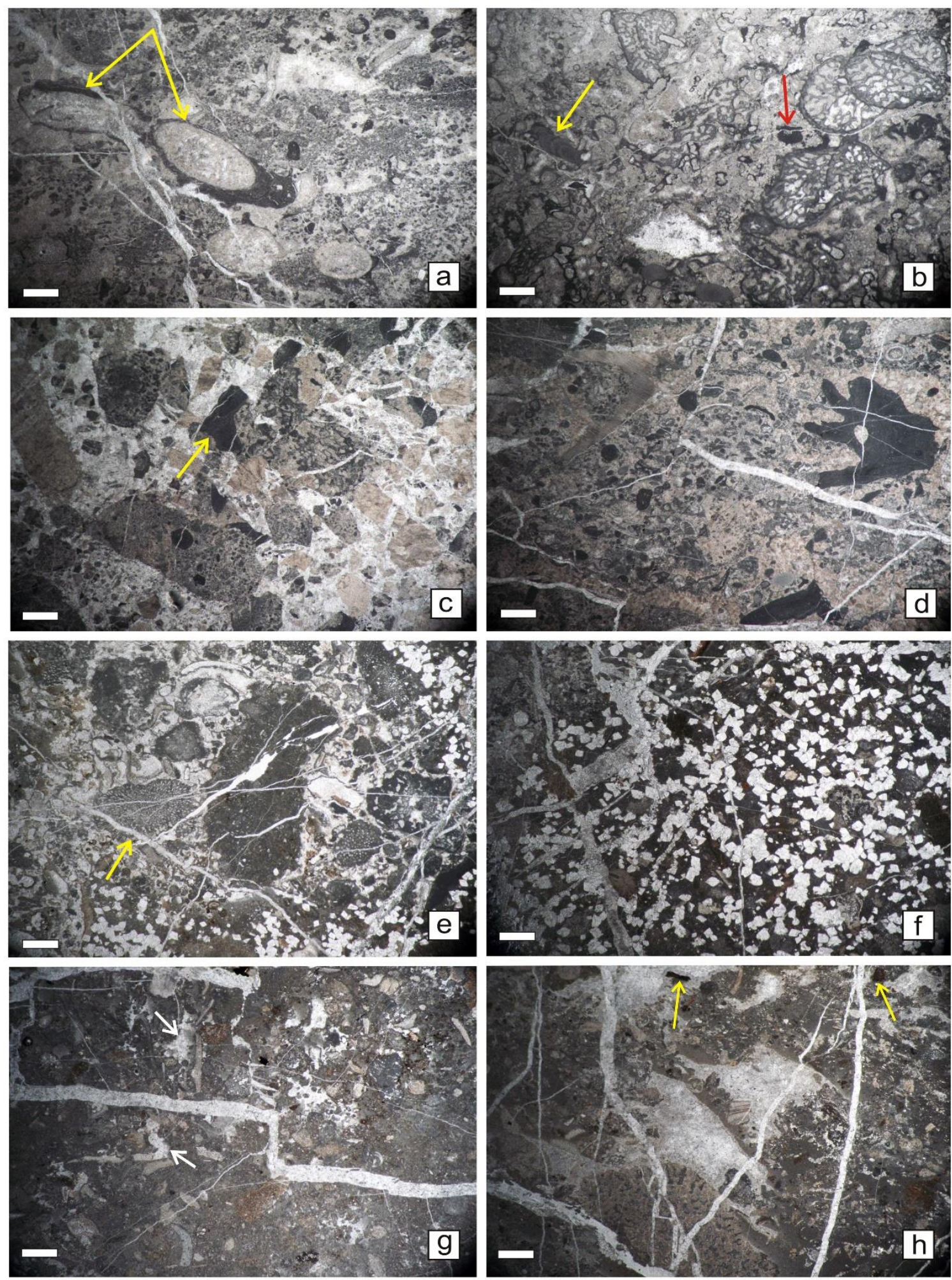

Fig. 3 a Boundstone with peloidal packstone-grainstone internal sediment. Corals are encrusted by Tubiphytes sp (yellow arrows); b Sponge bioconstruction with Solenolmia manon manon. The internal sediment contains encrusting organisms (Tubiphytes sp.-red arrow, Ladinella porata-yellow arrow); c Brecciated intraclastic peloidal rudstone with encrusting organism (Tubiphytes sp.-yellow arrow); d Bioclastic grainstone with encrusting organisms; e Dolomitized wackestone-packstone. It contains abundant cyanobacteria nodules (Rivularia sp.-yellow arrow), bivalves and gastropods. Euhedral dolomite crystals are present within the micritic sediment; f Dolomitized wackestone-packstone with cyanobacteria nodules and black pebble type intrasclasts; $g$ Fenestral wackestone-packstone with cyanobacteria (Rivularia sp.), fragments of "Solenopora" sp. and bivalves. Millimetre sized fenestral structures (white arrows) contain vadose silt and geopetal sediment. Meniscus micrite is present between peloids and other intraclasts; $\mathbf{h}$ Fenestral wackestone with black pebbles (yellow arrows). It contains rare bivalves and cyanobacteria nodules. The fenestral structures contain vadose silt and geopetal sediment. a: sample 80, Olt Gorges section; b: sample 77, Olt Gorges section; c: sample 55, Olt Gorges section; d: sample 30, Old Racoș Quarry; e, f: sample 173, Tipia Ormenişului section; g: sample 174, Tipia Ormenișului section; h: sample 175, Tipia Ormenișului section. Scale bar: $1 \mathrm{~mm}$. 
Aitken (1967) considered that thrombolites form under subtidal conditions, more recent studies (Kennard, 1981; Feldmann and McKenzie, 1998) suggest that such microbial accumulations prefer low salinity, high energy settings.

\section{Microfacies association 3 (MFA3)}

This association contains two main microfacies types: peloidal bioclastic grainstone and packstone-grainstone. It is very frequent in the Olt Gorges section.

Bioclasts are represented by encrusting organisms (Tubiphytes sp.), calcareous sponges, echinoderm plates, rare coral fragments, gastropods, bivalves, foraminifera. Encrusting organisms and up to one millimetre-sized peloids dominate the grain spectrum. However, the occurrence of MFA3 is less common within the studied sections.

\section{Interpretation}

The presence of encrusting organisms and rare coral fragments indicate transport from a reefal area. However, the abundance of micritic sediment and well-rounded peloids may suggest a longer period of transport, on a distal shelf slope.

\section{Microfacies association 4 (MFA4)}

Wackestone-packstone with cyanobacteria nodules and black pebbles - and dolomitised wackestone-packstone (Fig. 3e-h) define this facies association which forms the basal part of the Tipia Ormenișului section. Bioclasts are represented by bivalves, gastropods, cyanobacteria nodules, ellianelacean algae. Micritic intraclasts are pigmented by organic matter. Other pigmented clasts include Rivularia type nodules and various bioclasts (bivalves, gastropods). In addition, the matrix contains abundant iron oxides and vadose silt. Meniscus micrite is well developed between some intraclasts. Dolomitisation is frequent. Euhedral dolomite crystals can replace the micritic sediment of these limestones. Only some blackened cyanobacteria keep their original structure. Sponges, cyanobacteria and gastropods can be recognised in the non-dolomitised facies types. Rare fenestral structures are filled with vadose silt and geopetal sediment.

\section{Interpretation}

Such sedimentological features indicate carbonate deposition in low energy, internal platform areas. The presence of fenestral structures and Rivularia type cyanobacteria indicates a restricted environment (possibly intertidal ponds). Subaerial exposure is suggested by the existence of vadose silt, meniscus micrite and black pebble type intraclasts (Strasser \& Davaud, 1983; Strasser, 1984).

\section{BIOSTRATIGRAPHY}

The micropaleontological association consists of foraminifera [Earlandia sp., Endoteba sp., Endotebanella sp., Endotriadella wirzi (Koehn-Zaninetti, 1969), Endotriadella sp., Glomospirella sp., Meandrospira dinarica Kochansky-Devide \& Pantić, 1966, Ophtalmidium sp., Paleolituonella sp., Reophax sp., Turriglomina mesotriasica (Koehn-Zaninetti, 1969) and Turriglomina sp., duostominid foraminifera] (Fig. 4a-1), microproblematic organisms [(Bacinella ordinata Pantić, 1972, Baccanella floriformis Pantić, 1971, Ladinella porata Ott, 1968, Perturbatacrusta leini Schlagintweit \& Gawlick, 2011, Plexoramea cerebriformis Mello, 1977, Radiomura cautica Senowbari-Daryan \& Schaffer, 1979, Tubipytes sp.)] (Fig. 5a-j), calcareous sponges [Celyphia zoldana Ott, Pisa \& Farabegoli, 1980, Colospongia catenulata catenulata Ott, 1967, Solenolmia manon manon (Münster, 1841)] (Fig. 6a-d).

Meandrospira dinarica is known mainly form the Anisian deposits (Premoli Silva, 1971; Zaninetti et al., 1972; Bucur et al., 1994; Kobayashi, 2008; Okay et al., 2014; Lehrmann et al., 2015).

The first occurrence of Endotriadella wirzi is at the Olenekian-Anisian boundary (Zaninetti, 1976; Dağer, 1980). However, it is frequently described from Anisian carbonate deposits (Dağer, 1978; Salaj et al., 1983; Oravecz-Scheffer, 1987; Rettori, 1995).

Turriglomina mesotriasica is mentioned mainly from upper Anisian-Ladinian deposits (Bucur et al., 1997; Rychlinski et al., 2013) and it has a biostratigraphic distribution which characterizes the lower Anisian-Carnian interval (Rettori, 1995; Nittel, 2006).

Radiomura cautica has a larger stratigraphic distribution within the Anisian-upper Aptian interval (Pleș et al., 2017). However, it was frequently described from Triassic (Senowbari-Daryan, 1984; Velledits et al., 2011) or Upper Jurassic (Pleș et al., 2015) deposits.

Perturbatacrusta leini is an encrusting organism which is well known from shallow-water, Kimmeridgian-Berriasian deposits (Schlagintweit \& Gawlick, 2011; Pleș et al., 2013). This paper probably represents the first mentioning of this microfossil from the Triassic deposits.

Baccanella floriformis was described by Pantić (1971) from the Ladinian carbonates. It is frequently associated with Plexoramea cerebriformis and Ladinella porata in Ladinian limestones (Balogh \& Kovacs, 1976; SenowbariDaryan et al., 1993; Popescu, 1998; Gale et al., 2018).

Solenolmia manon manon is a calcareous sponge which was frequently mentioned from the Ladinian deposits. It was assigned to the Ladinian-lower Carnian interval by Balogh and Kovacs (1976). Other authors described this species from the Anisian-Carnian deposits of the Tethyan Realm (Senowbari-Daryan \& Garcia Bellido, 2002; Senowbari-Daryan et al., 2011)

Ott et al. (1980) described Celyphia zoldana from the Anisian limestones. Its occurence was also reported from the Anisian by Senowbari-Daryan et al. (1993, 2011) and Emmerich et al. (2005).

Colospongia catenulata catenulata was mentioned for the first time from the Ladinian-Carnian carbonates by Balogh \& Kovacs (1976). This calcareous sponge is also known from other localities of the Tethyan Realm, especially from the Ladinian-Carnian deposits (Senowbari-Daryan et al., 2011).

\section{DISCUSSIONS}

The studied Triassic carbonates characterize a shallow-water, high-energy environment. The identified facies associations define a shelf margin area with associated coralsponge bioconstructions encrusted by microproblematic organisms. Rudstone facies types were accumulated on a fore-reef slope, in the proximity of a reefal crest. Angular 

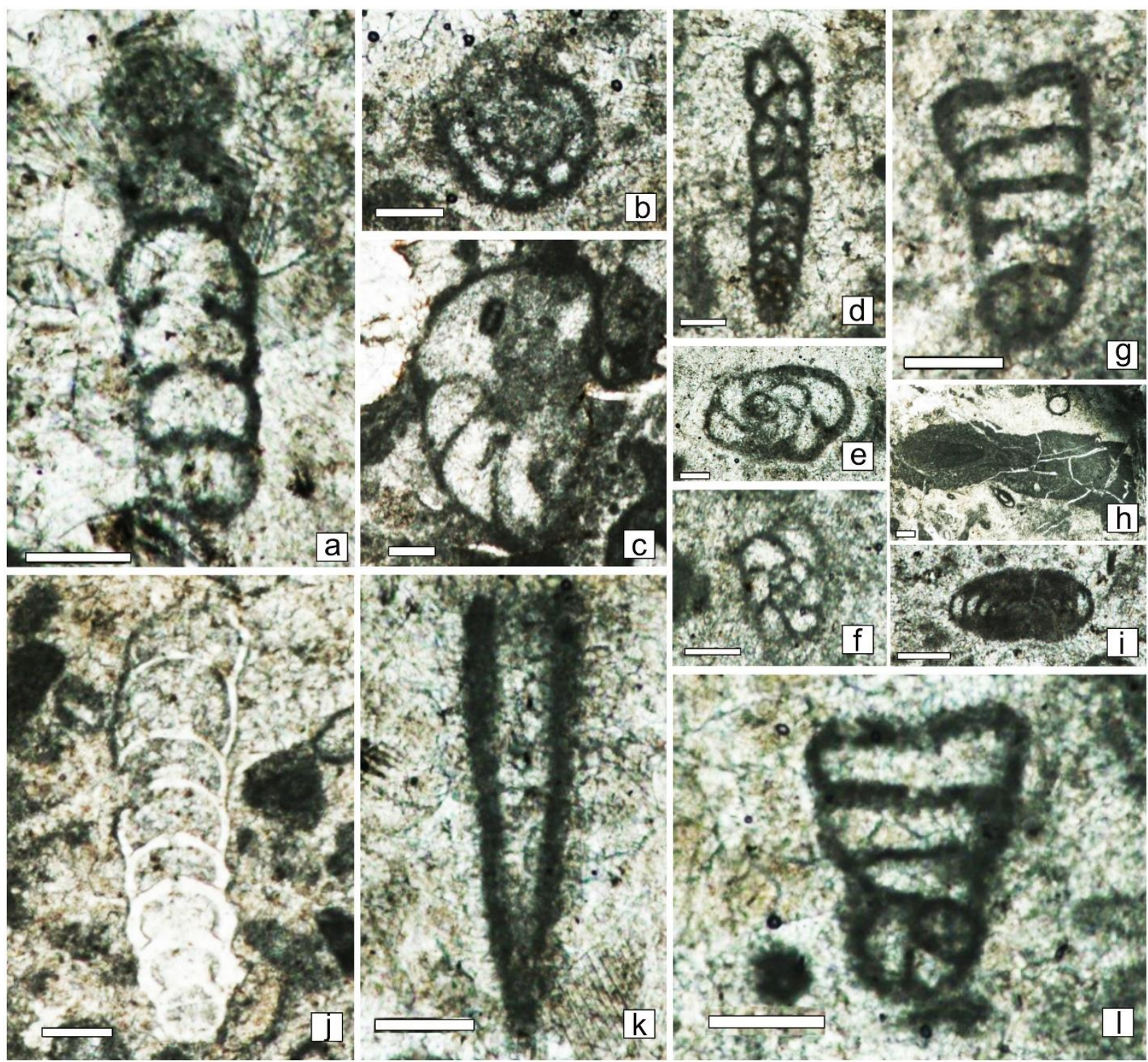

Fig. 4 Foraminifera from the Triassic limetones of the studied area. a Endotriadella wirzi Koehn-Zaninetti; b Meandrospira dinarica Kochansky-Devidé \& Pantić; $\mathbf{c}$ Duostominid foraminifera; d Turriglomina mesotriasica Koehn-Zaninetti; e Endoteba sp; f Endotriada sp.; g, l Paleolituonella sp.; h, i Ophtalmidium sp; j Nodosariid foraminifera; k Earlandia sp. a: sample 20, Old Racoș Quarry; b: sample 19B, Old Racoș Quarry; c: sample 9, Old Racoș Quarry; d: sample 219, Tipia Ormenișului section; e: sample 40, Olt Gorges section; f: sample 44, Olt Gorges section; g, h: sample 183, Tipia Ormenișului section; i: sample 52, Olt Gorges section; j: sample 39, Olt Gorges section; k: sample 19c, Old Racoș Quarry; 1: sample 118, Tipia Racoșului section. Scale bar: 0.25 $\mathrm{mm}$.

clasts were subjected to short periods of transport. The presence of coral and sponge fragments in association with encrusting organisms points to a reefal origin of these bioclasts. Microproblematic encrusting organisms are well known for their role in stabilising reefal bioconstructions (Reitner, 2013). Baccanella floriformis prefers high-energy shallow conditions (Martini et al., 2004; SanchezBeristain, 2010; Sanchez-Beristain \& Reitner, 2018). This microproblematic organism is frequently associated with bioconstructions or rudstone deposits. In addition, Ladinella porata prefers well lit shallow-water settings (Sanchez-Beristain \& Reitner, 2012, 2016, 2018, 2019). The packstone-grainstone and grainstone facies are defined by increasing proportions ofTubiphytes sp., commonly associated with depositional environment deepening (Aurell \& Badenas, 2004).
The inner platform facies (black pebble-bearing wackestone) were accumulating in restricted intertidal ponds. This fact is confirmed by the presence of Rivularia type cyanobacteria and fenestral structures (Lucia, 1972). Subaerial exposure is indicated by the presence of blackened bioclasts and vadose silt in association with meniscus micrite (Strasser \& Hillgärtner, 1998). Dolomitisation may occur simultaneously with carbonate subaerial exposure in an intertidal-supratidal depositional setting. Such processes were described by different authors [Assereto \& Kendall (1971), Jadoul et al. (1992)] from the Ladinian carbonate deposits of the Italian Alps.

The sedimentological features share common characteristics with the Wetterstein-type facies. Similar limestones were described by several authors from Hungary (Balogh \& Kovacs, 1976; Senowbari-Daryan et al., 2011; Velledits et al., 2011; Horvath \& Hips, 2015), Italy (Senowbari- 

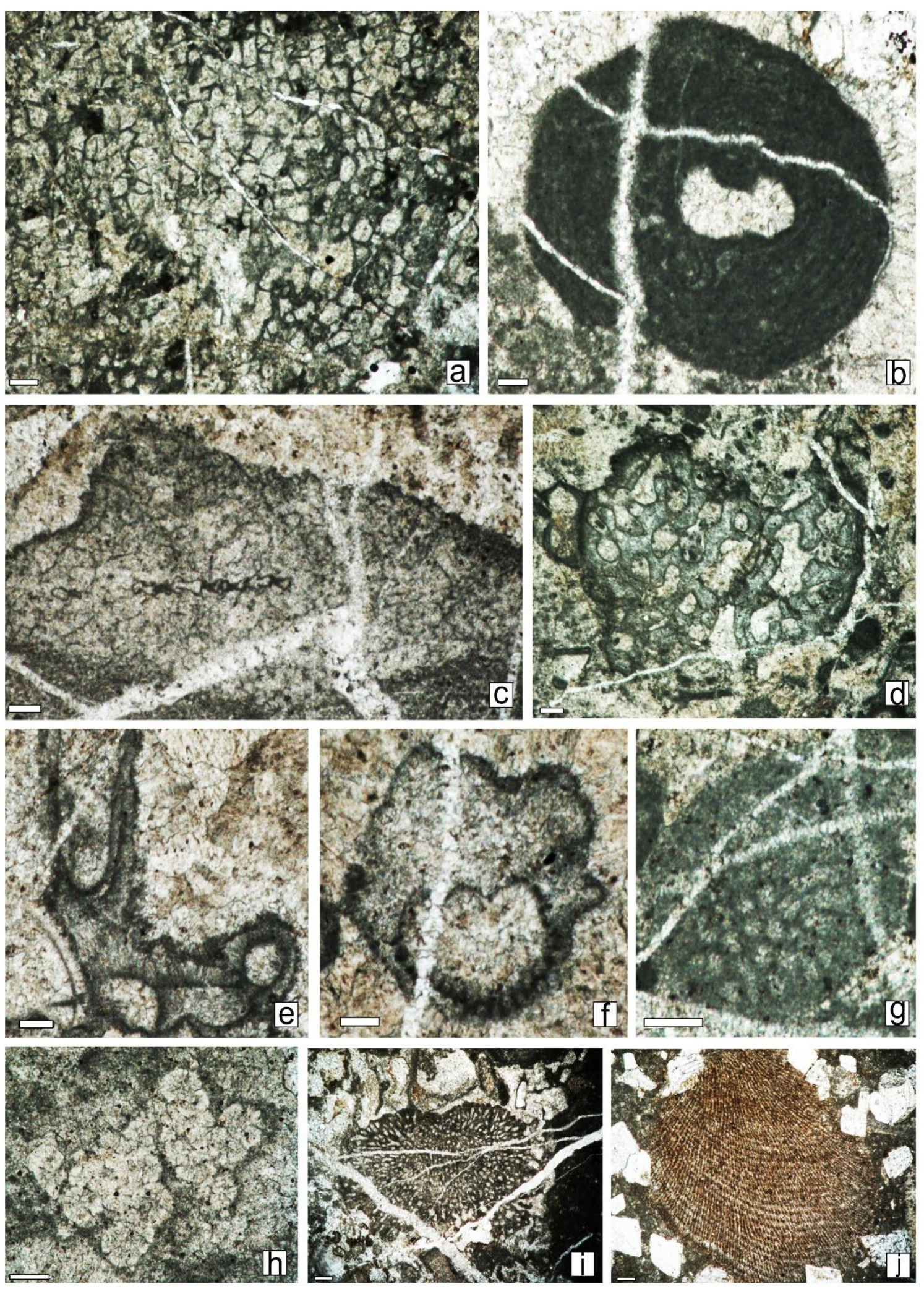

Fig. 5 Microproblematic organisms from the Triassic limestones of the studied area. a Bacinella ordinata Pantić. b Tubiphytes sp. c Plexoramea cerebriformis Mello. d Perturbatacrusta leini Schlagintweit \& Gawlick. e Radiomura cautica Senowbari-Daryan \& Scheffer. f Taumathoporella parvovesiculifera (Raineri). g Ladinella porata Ott. $\mathbf{h}$ Baccanella floriformis Pantić. i Rivularia sp. j "Solenopora" sp. a: sample 52, Olt Gorges section; b: sample 90, Olt Gorges section; c: sample 38, Olt Gorges section; d: sample 74, Olt Gorges section; e: sample 143, Tipia Racoşuluai section; f: sample 39, Olt Gorges section; g: sample 47, Olt Gorges section; h: sample 75, Olt Gorges section. Scale bar: a-c, e-h: $0.25 \mathrm{~mm}$; d, i-j: $0.5 \mathrm{~mm}$. 

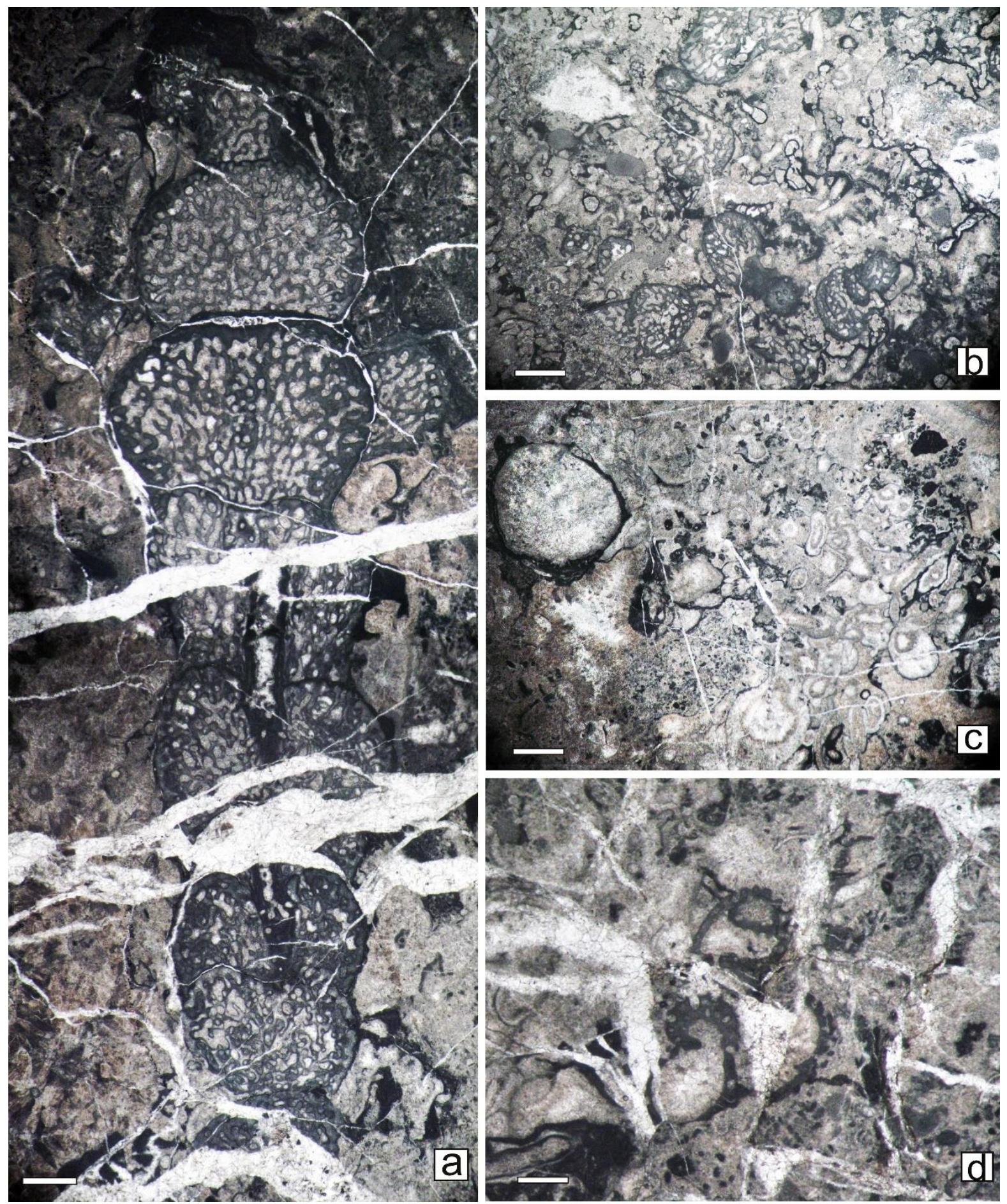

Fig. 6 Sponges from the Triassic limestones of the studied area. a,b Solenolmia manon manon (Münster). c Celyphia zoldana Ott, Pisa \& Farabegoli. d Colospongia catenulata catenulata Ott. a: sample 13, Olt Gorges section; b: sample 77, Olt Gorges section; c-sample 103, Tipia Racoșului section; d: sample 195, Tipia Ormenișului section. Scale bar: $1 \mathrm{~mm}$.

Daryan et al., 1993) and Romania (Dragastan \& Grădinaru, 1975; Bucur et al., 1994).

Patrulius et al. (1996) described three types of Upper Triassic carbonate successions from the Olt Gorges: (1) a Carnian-Norian (Tipia Ormenișului) massive, coralsponge bioconstructions overlying Hallstat-type limestones of reduced thickness; (2) Norian coral bioconstructions covering mafic and ultramafic rocks (Surmanul), and (3) Carnian-Norian alternances of Hallstatt-type limestones and coarse carbonates (Pietrele lui Murgoci). Some of the identified microfossils (e.g. Turriglomina mesotriasica) indicate a Ladinian-Carnian age for the carbonate succession from the Tipia Ormenișului Hill. Such microfossils are associated with Ladinian-Cranian microproblematic organisms (e.g. Baccanella floriformis, Ladinella porata) or sponges (e.g. Colospongia catenulata). The underlying Hallstatt-type limestones were biostratigraphically assigned by Patrulius et al. (1996) to the Carnian-Norian interval based on some poorly preserved ammonites (Arcestes sp.). However, the biostratigraphic range of the microfossils from the overlying limestones is limited to the Carnian. Thus, the age of the massive reefal 
succession from the Tipia Ormenișului hill could be restricted to this interval.

The Norian age of the Surmanul olistolith is indicated by a rich association consisting of brachiopods and bivalve fragments (Monotis haueri) (Patrulius et al.,1996). However, Anisian foraminifera (e.g. Meandrospira dinarica, Endotriadella wirzi) and Ladinian microproblematica (e.g. Ladinella porata, Plexoramea cerebriformis) are present in the Old Racoș Quarry sector (200 m to the east, samples 1-31) and the Olt Gorges. Thus, some of the Carnian-Norian limestones mapped by Popescu et al. (1976) could be older, probably Anisian-Ladinian or Carnian. The Anisian facies types (Old Racoș Quarry) are strikingly similar with the Steinalm-type facies described by Patrulius et al. (1996) from the Perșani Nappe olistoliths (Rica and Hăghimaşului Hill). The latter contain the same type of microfossils as those presented in this study (e.g. Meandrospira dinarica, Glomospirella sp., Endotriadella wirzi). As a consequence, some of the carbonate olistoliths presented in this paper could form an integrating part of the Perșani Nappe and not the Olt Nappe as indicated by former studies performed in the area.

\section{CONCLUSIONS}

Microfacies analysis was performed on carbonate samples belonging to the Triassic succession of the different Transilvanian Nappes that are present in the Perșani Mountains. This analysis indicates the presence of shallow-water high-energy reefal bioconstructions where corals and sponges were thriving in optimal environmental conditions. Encrusting organisms played a key role in building such reefal frameworks. Numerous bioclasts and angular/subangular intraclasts were transported on a forereef slope from shelf margin areas. Bioclasts are represented mainly by corals, sponges and encrusting organisms. The micropaleontological associations indicate Anisian-Ladinian and Carnian ages for the studied carbonate deposits. Previous studies indicated an Upper Triassic (Carnian-Norian) age for these limestones. The AnisianLadinian age of some of the studied olistolith suggests that they could belong to the Perşani Nappe and not to the Olt Nappe as considered before.

\section{ACKNOWLEDGEMENTS}

The authors would like to thank Eugen Grădinaru and Francisco Sanchez Beristain for their valuable comments that helped improve the quality of the manuscript.

\section{REFERENCES}

Aitken, J.D., 1967. Classification and environmental significance of cryptalgal limestones and dolomites, with illustrations from the Cambrian and Ordovician os southwestern Alberta. Journal of Sedimentary Petrology, 37: 1163-1178.

Assereto, R. \& Kendall, C.St.C., 1971. Megapolygons in Ladinian limestones of Triassic of Southern Alps: evidence of deformation by penecontemporaneous desiccation and cementation. Journal of Sedimentary Petrology, 41(3): 715-723.
Balogh, K. \& Kovacs, S., 1976. Sphinctozoa from the Reef Facies of the Wetterstein Limestone of Also-Hegy (South Gemericum, West Carpathians, Northern Hungary). Acta Mineralogica Petrologica Szeged, 22(2): 297-310.

Bucur, I.I., Strutinski, C. \& Pop, D., 1994. Middle Triassic Carbonate Deposits and Calcareous Algae from the Sasca Zone (Southern Carpathians, Romania). Facies, 30: $85-100$.

Bucur, I.I., Strutinski, C. \& Paica M., 1997. A new occurence of Triassic deposits NE of Oravița (Southern Carpathians, Rumania) and its paleotectonic significance. Geologica Carpathica, 48(1): 39-48.

Buser, S., Ramovš, A., Turnšek, D., 1982. Triassic reefs in Slovenia. Facies, 6: 15-24.

Dağer, Z., 1978. Sur quelques Foraminiferes nouveaux du Trias de Kocaeli, Turquie. Notes du Laboratoire de Paléontologie de l'Université de Genève, 4: 21-74.

Dragastan, O \& Grădinaru, E., 1975. Asupra unor alge, foraminifere, sphinctozoare şi microproblematice din Triasicul din Carpații Orientali și Dobrogea de Nord. Studii și cercetări de geologie, geofizică, geografie., Seria Geologie, 20(2): 247-254.

Dragastan, O., Diaconu, M., Popa, E., Damian, R., 1982. Biostratography of the Triassic formations in the East of the Pădurea Craiului Mountains. Dări de Seamă ale Institului Geologic și Geofizic, 67 (4) (for 1979-1980): 29-61.

Dunham, R.L., 1962. Classification of carbonate rocks according to depositional texture. American Association of Petroleum Geologists Memoir, 1: 108-12Embry, A. F. \& Klovan, J.E., 1971. Late Devonian reef tract on northwestern Banks Island. Bulletin of the Canadian Society of Petroleum Geology, 19: 730-781.

Emmerich, A., Zamparelli, V., Bechstädt, T. \& Zuehlke, R., 2005. The reefal margin and a slope of a Middle Triassic carbonate platform: The Latemar (Dolomites, Italy). Facies, 50(3): 573-614.

Feldmann, M., McKenzie, J.A., 1998. Stromatolite-thrombolite associations in a modern environment, Lee Stocking Island, Bahamas. Palaios, 13: 201-212.

Flügel, E., Ramovš, A., Bucur, I.I., 1994. Middle Triassic (Anisian) Limestones from Bled, Northwestern Slovenia. Geologija, 36(1): 157-181.

Gaetani, M., Fois, E., Jadoul, F., Nicora, A., 1981. Nature and evolution of Middle Triassic carbonate buildups in the Dolomites (Italy). Marine Geology, 44: 25-57.

Gale, L., Peybernes, C., Bogomir, C. \& Hočevar, C., 2018. Biotic composition and microfacies distribution of Upper Triassic build-ups: new insights from the Lower Carnian limestone of Lesno Brdo, central Slovenia. Facies, 64(3): 1-24.

Horvath, B. \& Hips, K., 2015. Microfacies associations of Middle and Upper Triassic slope and basin carbonates deposited along the Neo-Tethyan margin, NE Hungary. Austrian Journal of Earth Sciences, 108(1): 3441.

Istocescu, D., Dragastan, O., 1978. Les occurences triasiques du basin de Beiuș (Monts Apuseni). Dări de Seamă ale Institutului Geologic și Geofizic, 64(4): 137-145.

Jadoul, F., Gervasutti, M. \& Fantini Sestini, N., 1992. The Middle Triassic of the Brembana Valley: Preliminary 
study of the Esino Platform (Bergamasc Alps). Rivista Italiana di Paleontologia i Stratigrafia, 98(3): 299-324.

Kennard, J., 1981. The Arrinthrunga Formatrion: Upper Cambrian epeiric carbonates in the Georgina Basin, central Australia. Australia, Bureau of Mineral Resources, Geology and Geophysics Bulletin, 211: 1-30. Kobayashi, F., 2008. Early Anisian (Triassic) foraminifers from the Hiraki Formation of the Maizuru Terrane in the Tatsuno-Aioi area, Hyogo Prefecture, Japan. Journal of The Geological Society of Japan, 114(2): 80-87.

Lehrmann, D.J., Stepchinski, L., Altiner, D., Orchard, M.J., Montogmery, P., Enos, P., Ellwood, B.B., Bowring, S.A., Ramezani, J., Wang, H., Wei, J., Yu, M., Griffiths, J.D., Minzoni, M., Schaal, E.K., Li, X., Meyer, K.M. \& Payne, J.L., 2015. An integrated biostratigraphy (conodonts and foraminifers) and chronostratigraphy (paleomagnetic reversals, magnetic susceptibility, elemental chemistry, carbon isotopes and geochronology ) for the Permian-Upper Triassic strata of Guandao section, Nanpanjiang Basin, south China. Journal of Asian Earth Sciences, 108: 117-135.

Lucia, F.J., 1972. Recognition of evaporite-carbonate shoreline sedimentation. In: Rigby, J.K. (ed.) Recognition of ancient sedimentary environments, Society of Economic Paleontologists and Mineralogists 16, pp. 160-191.

Mantea, G., 1985. Geological studies in the upper basin of the Someșul Cald valley and the Valea Seacă valley region (Bihor-Vlădeasa Mountains). Anuarul Institutului de Geologie şi Geofizică 66: 1-85.

Martini, R., Zaninetti, L., Lathullière, B., Cirilli, S., Cornée, J.-J. \& Villeneuve, M., 2004. Upper Triassic carbonate deposits of Seram (Indonesia): palaeogeographic and geodynamic implications. Palaeogeography, Palaeoclimatology, Palaeoecology, 206: 75-102.

Nittel, P., 2006. Beiträge zur Stratigraphie und Mikropälaeontologie der Mitteltrias der Innsbruker Nordkette (Nordliche Kalkalpen, Austria). Geologia Alpina, 3: 93-145.

Oravec-Scheffer, A., 1987. Triassic foraminifers of the Transdanubian Central Range. Geologica Hungarica Seria Paleontologica, 50: 3-331.

Okay, A.I., Altiner, D. \& Kilic, A.M., 2014. Triassic limestone, turbidites and serpentinite-the Cimmeride orogeny in the Central Pontides. Geological Magazine, 152(3): 460-479.

Ott, E., Pisa, G., Farabegoli, E., 1980. Celyphia zoldana sp. n., a reef building sphinctozoan sponge in Anisian limestones of the Southeastern Dolomites. Rivista Italiana di Paleontologia i Stratigrafia, 85(3-4): 829-842.

Pantić, S., 1971. Baccanella floriformis n. gen. n. sp. from the Middle Trassic of the Dinarides. Annales Géologiques de la Péninsule Balcanique, 36: 105-111.

Patrulius, D., 1996. The Triassic and Lower Jurassic formtions of the Transylvanian Nappe-System (East Carpathians-Romania). Memoriile Institutului Geologic al României, 36: 21-30.

Patrulius, D., Popa, E. \& Popescu, I., 1966. Autochtonous Mesozoic series and the Transylvanian Decollement Nappe in the surroundings of Comana (Perșani Mountains). Anuarul Comitetului Geologic, 35: 305-444 (in Romanian).
Patrulius, D., Mirăuță, D. \& Gheorghian, E., 1996. The Klippen of the Perșani Mountains (East Carpathians). Memoriile Institutului Geologic al României, 36: 3153.

Pleș, G., Bucur, I.I. \& Păcurariu, A., 2015. Foraminiferal assembalges and facies associations in the Upper Jurassic carbonates from Ardeu Unit (Metaliferi Mountains, Romania). Acta Palaeontologica Romaniae, 11(2): 43-57.

Pleş, G., Mircescu, C.V., Bucur, I.I. \& Săsăran, E., 2013. Encrusting micro-organisms and microbial structures in Upper Jurassic limestones from the Southern Carpathians (Romania). Facies, 59: 19-48.

Pleş, G., Bîrtaş, T., Chelaru, R. \& Bucur, I.I., 2017. Crescentiella morronensis (Crescenti) (incerte sedis) dominated microencruster association in Lower Cretaceous (lower Aptian) limestones from the Rarău Massif. Cretaceous Research, 79: 91-108.

Popa, E., Dragastan, O., 1973. Triassic (Anisian-Ladinian) algae and foraminifera from the eastern part of the Pădurea Craiului Mountains (Apuseni Mountains) (in Romanian). Studii și cercetări geologice, geofizice şi geografice, Geologie, 18(2): 425-442.

Popescu, D.A., 1998. Sur la présence de l'espèce Bacanella floriformis Pantić dans le Trias moyen de la nappe bucovinique du synclinal Rarău. Analele științifice ale Universității Alexandru Ioan Cuza din Iași, Geologie, 44: 43-47.

Popescu, D.A., 2001. Geological study of the Triassic limestones from the Piatra Zimbrului klippen (Rarău Syncline, Eastern Carpathians).

Popescu, D.A., Popescu, L.G., 2004. Microfacies of the Triassic limestones in the Piatra Şoimului Klippe (Transilvanian Nappes, Rarău Syncline, Eastern Carpathians, Romania). Studia UBB Geologia, 64(1): 87105.

Popescu, I., Mihăilă, N., Peltz, S., Țicleanu, M. \& Andreescu, I., 1976. Geological map of Romania, 1:50 000 sheet 78 d-Racoș, Institute of Geology, Bucharest.

Premoli Silva, I., 1971. Foraminiferi anisici de la regione giudicariense (Trento). Rivista Italiana di Paleontologia i Stratigrafia, 77 (3): 303-374.

Reitner, J., 2013. Modern cryptic microbialite/metazoan facies from lizard Island (Great Barrier Reef, Australia). Formation and concepts. Facies, 29: 3-40.

Rettori, R., 1995. Foraminiferi del Trias inferiore e medio della Tetide: revisione tassonomica, stratigrafia ed interpretazione filogenetica. Publications du Département de Géologie et Paléontologie Université Genève, 18: 1-147.

Rychlinski, T., Ivanova, D.K., Jaglarz, P. \& Bucur, I.I., 2013. Benthic foraminifera and calcareous algae from the Anisian-Norian succession in the Tatras (Poland and Slovakia): New data from High Tatric and Križna units. Studia UBB Geologia, 58(1): 21-43.

Salaj, J., Borza, K. \& Samuel, O., 1983. Triassic foraminifers of the West Carpathians. In: Gasparikova, V. (ed.) Geologicky Ustav Dionyza Stura.

Sanchez-Beristain, F., 2010. Paleoecological and geochemical studies on

sponge/microencruster -bearing communities contained in selected Cipit Boulders from the St. Cassian Formation (Lower Carnian, Upper Triassic) of the Dolomites, 
Northeastern Italy. PhD Thesis, Georg August University of Göttingen, Göttingen, 224 pp.

Sanchez-Beristain, J.F., Reitner, J., 2012. Paleoecology of microencrusters and encrusting ,,coralline,, sponges in Cipit boulders from the Cassian formation (upper Ladinian-lower Carnian, Dolomites, northern Italy). Paläontol Zeitschrift, 86: 113-133.

Sanchez-Beristain, F. \& Reitner, J., 2016. Palaeoecology of new fossil associations from the Cipit boulders, St. Cassian Formation (Anisian-Ladinian, Middle-Upper Triassic; Dolomites, NE Italy). Paläontologische Zeitschrift, 90: 243-269.

Sanchez-Beristain, J.F., Reitner, J., 2018. Numerical analyses of selected microencrusters from the Cipit boulders of the St Cassian Formation (Dolomites, NE Italy): palaeoecological implications. Lethaia, 10.1111/let.12312.

Sanchez-Beristain, J.F., Reitner, J., 2019. Microbialitedominated fossil associations in Cipit Boulders from Alpe di Specie and Misurina (St. Cassian Formation, Middle to Upper Triassic, Dolomites, NE Italy). TIP Revista Especializada en Ciencias Químico-Biológicas, 22: 1-18.

Săndulescu, M., 1984. Geotectonics of Romania. Ed. Tehnică, Bucharest, 335 pp.

Schlagintweit, F. \& Gawlick, H.-J., 2011. Perturbatacrusta leini n. gen., n. sp. a new microencruster incertae saedis (? Sponge) from Late Jurassic to Earliest Cretaceous platform margin deposits of the Northern Calcareous Alps of Austria. Facies, 57(1): 123-135.

Senowbari-Daryan, B., 1984. Mikroproblematika aus den obertriadishen Riffkalken von Sizilien. Münstersche Forschungen zur Geologie und Palaeontologie, 61: 181.

Senowbari-Daryan, B., Garcia-Bellido, D.C., 2002. Fossil 'Sphinctozoa': Chambered Sponges (Polyphyletic). In: Hooper, J.N.A. \& Van Soest R.W.M. (eds.) Systema Porifera: A Guide to the Classification of Sponges, Kluwer Academic/Plenum Publishers, Volume 2, p. 1151-1534.
Senowbari-Daryan, B., Zühlke, R., Bechstädt, T. \& Flügel, E., 1993. Anisian (Middle Triassic) Buildups of the Northern Dolomites (Italy): The Recovery of Reef Communities after the Permian/Triassic Crisis. Facies, 28: 181-256.

Senowbari-Daryan, B., Kovács S., Velledits, F., 2011. Sponges from the Middle Triassic reef limestone of the Aggtelek Karst (NE Hungary). Geologica Carpathica, 62(5): 397-412.

Strasser, A., 1984. Black pebble occurrence and genesis in Holocene carbonate sediments (Florida Keys, Bahamas and Tunisia). Journal of Sedimentary Petrology, 54: 1097-1109.

Strassser, A., Davaud, E., 1983. Black pebbles of the Purbeckian (Swiss and French Jura): lithology, geochemistry and origin. Eclogae Geologicae Helevetiae, 76: 551-580.

Strasser, A. \& Hillgärtner, H., 1998. High-frequency sealevel fluctuations recorded on a shallow carbonate platform (Berriasian and lower Valangian of Mont Salève, French Jura). Eclogae Geologicae Helvetiae, 91: 375390.

Velledits, F., Péró, C., Blau, J., Senowbari-Daryan, B., Kovács, S., Piros, O., Pocsai, T., Szügyi-Simon, H., Dumitrică, P. \& Pálfy, J., 2011. The oldest Triassic platform margin reef from the Alpine-Carpathian Region (Aggtelek, NE Hungary): platform evolution, reefal biota and biostratigraphic framework. Rivista Italiana di Paleontologia e Stratigrafia, 117(2): 221-268.

Zaninetti, L., 1976. Les foraminiferes du Trias. Essai de synthèse et corrélation entre les domains mésogéens européen et asiatique. Rivista Italiana di Paleontologia e Stratigrafia, 82 (1): 1-258.

Zaninetti, L., Brönnimann, P., Baud, A., 1972. Essai de zonation d'après les Foraminiferes dans l'Anisien moyen et supérieur des Préalpes medians rigides (Préalpes romandes, Suisse, et Préalpes du Chablais, France). Eclogae Geoogicae Helvetiae, 65(2): 343-353. 